This is an Accepted Manuscript of an article published by Taylor \& Francis in Journal of War \& Culture Studies on 07/11/2019, available online:

https://www.tandfonline.com/doi/full/10.1080/17526272.2019.1687987 


\title{
Title: Vile Incubator: A pathology of the Cold War bunker.
}

\begin{abstract}
:
This article presents a 'pathology' of the Cold War bunker via an analysis of the decay, entropy and post-human fecundity to be found within the closed system of these now abandoned man-made protective cavities. Opening with a contextual overview of current research in bunker studies, and providing an orientation to the variety of bunkers to be found across the US, UK and Europe, the article then presents fieldwork in recently opened bunker caves on the Norwegian island of Tjøme, foregrounding the complex's after-life as an incubator for the extremophilic organisms and crystalline formations growing within it. These inhabitants adapt the bunker, producing a post-human 'bunker culture' of sorts, manifested in alien forms of survival and inter-organism conflict, that strangely echo Cold War science's research into entropy and cybernetics, and that war's co-option of matter and culture to apocalyptic, existential ends.
\end{abstract}

Keywords: bunker, Cold War, entropy, pathology, mycelium, efflorescence, fungi.

Vile Incubator: A pathology of the Cold War bunker. 
In [J. Willard] Gibb's Universe order is least probable, chaos most probable. But while the Universe as a whole, if indeed there is a whole Universe, tends to run down, there are local enclaves whose direction seems opposed to that of the Universe at large and in which there is a limited and temporary tendency for organization to increase. Life finds its home in some of these enclaves.

Pamela Zoline, The Heat Death of the Universe (1988, p.26).

\section{Introduction}

Maybe the humans were crushed in the stampede to evacuate the cities or incinerated in the epicentre of nuclear blast, or foolishly chose to endure the contamination of the ashen fallout. Perhaps the catastrophe never happened or was simply deferred indefinitely. Either way, the darkness of the subterranean bunker remains undisturbed, unpopulated and sealed against a world of multiplying catastrophic possibilities. In the absence of human life, the lightless cavity is unaware of the existential threat that defined its design and construction, and is unaware of its own eventual obsolescence. The bunker is a negative space, a forgotten pocket of stale air sealed in a mountainside, or under a fallow pasture, or beneath a suburban cul-desac. All bunkers were made to shield, but Cold War bunkers - the particular focus of this article - were made (or retrofitted from previous conflicts) to protect humans against the ultimate energy-drain, the sudden, accelerated dissipation of energy in a thermonuclear blast and the mass destruction of organic life. And yet, unopened and unadulterated, these bunkers are a subterranean monument to the Second Law of Thermodynamics, otherwise defined as entropy, which is a measure of the inherent tendency towards the dissipation of matter and useful energy. Entropy also governs the process of ruination and decay that will eventually undermine the bunker's façade of perpetual preservation. However, the Cold War bunker also offers the possibility of homeostasis, a condition which is constant and unchanging, and 
suspends (albeit temporarily) the process of entropy - while everything above is in constant, hysterical flux.

There is a growing body of work on the after-life of Cold War bunkers and hardened shelters, from the process of exploration (Bennett et al, 2017) and appropriation as heritage sites (Bowers and Booth 2017; Hermann 2017), to their emergence as an exotic class of real estate for the super-rich, the super-paranoid or the chthonically inclined (Garrett and Klinke 2018). However, apart from a recent study of Second World War bunkers as shelters for mammals (Jumeau et al, 2018), or the 'doomed colony' of ants that somehow survived in a Polish bunker with no recognisable food source (Czechowski et al, 2016), very few studies relate to bunkers without humans, as habitats for non-human organisms, or as environments which are subject to unique forms of material ruination and transformation. Maria Alejandra Pérez' study of Cold War bunker-caves in Greenbier County, West Virginia is an exception, detailing the geological and hydrological consequences of building Cold War bunkers in caves (Alejandra Pérez 2017).

This article will explore the paradox of the Cold War bunker as a powerful symbol of entropic ruination, and an enclave of constancy and survival. Despite being the architectural actualisation of a premature burial site (as a potential prison for the living dead), the sealed bunker is not without life or even culture. In the following text, we will break into the Cold War bunker and explore the apparent agents of entropy that persist and sometimes thrive within its confined walls. The article will argue that the closed bunker is a kind of incubator for extremophilic organisms and crystalline formations - fungi, mildews, moulds flourishing within dank atmospheres and on surfaces oozing with unfettered efflorescence. Here, the exploration is framed as a pathology of the bunker, an analysis of biological, organic and 
crystalline cultural production occurring within such spaces, processes which critically undermined the functional integrity of such spaces. In this respect, the article will explore the bunker's other cultures, that which exist in the absence of human beings, their politics, discourse, or capacity for self-destruction. While pathology as a clinical method might ordinarily describe how certain processes undermine the crucial functionality of a living subject, here we will explore how a certain type of architecture can be critically undermined by a combination of organic, mineral and hydrological processes. It will approach this pathology with reference to fieldwork on a specific de-militarised facility, Torås Fort on the Norwegian island of Tjøme which was once a Second World War naval battery, but which subsequently became a Cold War military training facility (Sørlie 2009). The fieldwork focuses on recently opened mountain tunnels which were retrofitted during the Cold War for the NATO 'Stay behind' programme. The fieldwork presentation, with its focus on organic life and material decay, will then lead on to a more speculative analysis of the concept of entropy, both as a broader cultural metaphor for ruination, decay and obsolescence and as a measure of energy release and dissipation within the Second Law of Thermodynamics. As we will see, the development of entropy as a key trans-disciplinary concept in the sciences and the arts, emerges in the first half of the Twentieth Century but later coalesces as a significant cultural trope during the Cold War period. The pioneering work of Norbert Wiener on entropy will be addressed in relation to its subsequent impact on cybernetics as a highly influential method for the introduction of regulating systems and feedback loops within military applications. This article will demonstrate how, through his work on entropy, Wiener's legacy would change the course of the Cold War. However, it will also address Wiener's believed that life itself somehow resists the inevitability of the Second Law, like enclaves of constancy in a universe of entropic dispersal. The article will then demonstrate how the concept of entropy emerged as a significant cultural theme in the creative arts during 
the 1960s, providing a method for artists and writers such as Pamela Zoline, Thomas Pynchon and Robert Smithson to study the materiality and granularity of architecture and infrastructure through the lens of deep time and in the context of nuclear and universal destruction. Set against the context of the Cold War, the concept of entropy will be brought to bear on the phenomenon of the hardened, subterranean bunker and its ability to preserve human life and nurture other, unexpected lifeforms. Finally, the article will explore entropy, (psycho)pathology and the Cold War bunker in relation to Paul Virilio's notion of the military institution as a 'cyclothymic animal', asleep during peace time and awake for war (1994, p.21).

\section{An array of bunkers}

Bunkers come in many shapes and sizes and this article cannot present a taxonomy (for that see, for example, Cocroft et al 2004). However, the essential features of Cold War bunkers remain simple: they are subterranean spaces (or semi-submerged), specifically constructed to preserve human life (and/or store supplies and weapons) for a matter of days or months against attack and the hostile environmental conditions thereafter (e.g., radioactive fallout).

The urge to burrow against attack from above is nothing new. The increasing power and range of artillery projectiles in the early modern era forced a radical redesign of the fortress, reducing its visible presence in the landscape, flattening it and endowing it with low level architectural features such as bastions, ravelins and glacis to divide assaulting forces and deliver lethal flanking fire from overlapping vantage points (Hirst 2005, p.182). World War I saw the widespread use of trenches on the battle field as temporary protection against waves of artillery and small arms fire, and in World War II the threat of aerial attack forced civilians and military personnel unground, digging shelters and vast complexes to shield against 
bombardment and firebombing (see, for example, Bosma 2012). World War II also saw the race to develop nuclear weapons with the potential to destroy whole cities, kill millions of people, and render large areas of the planet uninhabitable. The deadly potential of nuclear weapons was seared into the global imagination with the destruction of the Japanese cities of Hiroshima and Nagasaki which instantly killed hundreds of thousands of people and effectively ended World War II in August 1945. The ensuing Cold War arms race between the USA and the Soviet Union over the next 45 years brought the world, by accident and by design, perilously close to nuclear Armageddon on a number of notable occasions (Herzog 2014, Schlosser 2014)

With the tentative postponement of nuclear annihilation, the end of the Cold War saw the signing of a number of key nuclear arms reduction treaties, a process which also precipitated the obsolescence of associated weapons infrastructure and technologies. As they became abandoned, and seemingly no-longer needed, there was a gradual public disclosure of hidden networks of secret shelters, buried deep underground and built to house key government workers, military personnel and certain wealthy or well-connected groups. Between 19451990, these facilities had been built in almost every country in the northern hemisphere and aimed to provide a degree of state and military control in which 'the state's crucial organs could retreat in order to survive a war which would leave its territory destroyed and its population decimated, if not annihilated' (Garrett and Klinke 2018, p.3).

While the Swiss implemented a comprehensive programme of civil shelters for use in the event of a Soviet invasion or nuclear attack, enough to accommodate every single member of the population (Ziauddin 2017), British and Americans civilians had no such provision. Instead, their governments opted for education and preparation programmes that, in hindsight, bordered on the theatrical and performative rather than practical survival (Davis 
2007). It was assumed, at least by officials in the UK, Europe and the US, that when the critical infrastructure collapsed, the state apparatus would quickly follow creating mass civil unrest that could not be managed under planned civil defence strategies (Grant 2010). In the majority of case, therefore, only selected groups would enter subterranean bunkers in order to monitor fallout, coordinate civil defence and preserve the bare bones of government. The Cold War saw the UK divided into twelve, potentially autonomous regional zones, each with a 'Citadel' or Regional Seat of Government (RSG), and numerous Sub-Regional Headquarters (SRHQ) to gather and return data to central command. In its final iteration, there were approximately sixteen such sites around the UK (Cocroft et al. 2004, p.199), and a number of large underground government and military facilities in London. However, the scale of this undertaking was perhaps surpassed by the network of 1500 Royal Observer Corps (ROC) monitoring posts, built between 1956 and 1965, distributed in clusters across the UK.. Each one of these tiny underground shelters could sustain three personnel for up to twenty-one days while they conducted a variety of tests to determine the position and yield of an atomic explosion, and the intensity of the subsequent radioactive fallout. Each cluster of stations would gather data during an attack, communicating it to one of thirty group control centres which would then build a national picture of devastation and measure the spread of radioactive contamination.

In the USA, the programme of civil Cold War bunker and shelter building was only nominally supported by the government and remained largely the responsibility of individual families and local communities (McEnaney 2000). By contrast, there were the 'big bunkers' of the USA government, which provided a continuity of government and military support during and after a nuclear exchange. These included the North American Aerospace Defense Command's (NORAD's) vast command and control facility, the Cheyenne Mountain Complex. Thiscould house hundreds of personnel and sustain them for months, if not years, 
underground (see NORAD website) Other examples include the Raven Rock Mountain Complex at Blue Ridge Summit, Pennsylvania, which houses the emergency operation centres for the Army, Air Force and Navy (Graff 2017); the Greenbrier Mountain emergency bunker created for the United States Congress (McCamley 2013); the Mount Weather Emergency Operational Centre which is a centre of operations for The Federal Emergency Management Agency (FEMA) in Virginia (McCamley 2013); the ten Missile Master Nike air defence facilities distributed across the USA (Leonard 2015), and the Federal Reserve Bunker at the National Audio-Visual Conservation Centre in Culpeper, Virginia (Burke 2003).

But this bunker landscape is not unique to the USA. Stephen Graham estimates that there are approximately ' 10,000 deeply buried facilities in existence globally' (2016, p.342), a large proportion of which are undoubtedly hardened shelters from the Cold War era in various stages of decay and dilapidation. The specific nature and agency of such ruination will be explored in the following section. A browse through Facebook groups such as Cold War Bunkers and Bases reveal that across Europe, there are countless hardened and underground munitions depots, subterranean bunkers and control centres at demilitarized sites. In Canada, the 'Diefenbunkers' provided continuity-of-government and military support at fifty subsurface locations across the country (McCamley 2013). In Russia, the huge bunkers known as Mount Yamantau (Bashkortostan region) and Mount Kosvinsky (Severdlosk region) are both said to rival America's Cheyenne Mountain in scale and capacity.

Accordingly, large and/or widespread, bunker complexes are not just a figment of the fevered Cold War imagination; these structures were built, and they embodied an existential politics of selective survival- a politics materialised in the now-abandoned hollows of concrete caves 
and burrowed ground. I will now, via fieldwork, turn to consider the pathology of one such abandoned bunker.

\section{Torås Fort mountain complex.}

I have written before about Torås Fort on the Norwegian Island of Tjøme and presented images describing the ruination of the site using the scale of 'deep time' to provide an alternative context for military architecture (Flintham 2016, 2017). I proposed a 'geological' reading of such sites, emphasising the redeployment of minerals in the service of conflict, and a speculative exploration of violence as a form of energy that is transferred through various states of geological matter over the longue dureé. As a Second World War naval artillery station repurposed for the Cold War, Torås is remarkable for the way its numerous gun emplacements, barrack buildings and architectural elements blend into the undulating granite rock formations, disguising itself in the landscape while remaining a subtly imposing local presence. Its formidable command centre is a considerable feat of Nazi engineering by the Organisation Todt: a blockhouse with numerous stacked rooms concealed under a mountain of poured concrete and crowned with a square, flat observation post allowing unrestricted views of the island and out to sea (Sørlie 2009). The command centre is a brutal imitation of a mountain peak, one that nevertheless draws visitors to its base and up the steep concrete steps towards its impenetrable inner core. Visitors to the Torås complex also pass many sealed blast doors leading into the interior of the granite hillsides, welded shut when the complex was closed down in 1999. However, on a visit to the site in 2015 , I was able to accompany a local group of military enthusiasts who had gained access to the network of bunker tunnels for the first time only a matter of days previously. My account follows, written in present tense to give a sense of the unfolding subterranean landscape that I progressively encountered there. 
Starting out on our walk through the complex, we slowly pull open the foot-thick doors and walk past a giant exhaust outlet which stands sentry at the entrance to the first bunker tunnel (see Figure 1).

\section{[insert Figure 1.]}

The entrance corridor is roughly hewn from the dark larvikite granite, which is cold to the touch and damp with cool surface moisture, and extends about seven or eight metres into the hillside before we encounter another thick, steel door. This time though, the door has a small, square recess, just big enough for a single eye to peer through, or a gun to spray the tunnel with bullets. It is not clear if the corridor would have once been airtight, but we are clearly standing in a defensible antechamber. The ground is even but loose gravel grinds under our feet. We pass through the steel door and turn hard right, up some steps and into the first of two connected chambers with rounded ceilings, each about five metres wide by seven in length, and big enough to accommodate a dozen men with beds, provisions and ammunition. Many of the concrete walls are black with mould or puckered with layers of flaking paint and weeping scabs of dark rust. We leave the room and enter another almost identical one, empty except for a pair of free-standing spot lights which throw a halogen blaze into every fetid recess. Another blast door, another narrow granite tunnel, and a climb up some steep concrete steps. Then, into an irregular granite chamber which houses a large fuel tank and some ventilation equipment. All of this equipment and technology is definitely post-Second World War, retrofitted during the Cold War at a time of tense border negotiations and territorial disputes. Our guides are a group of military and historical enthusiasts, who explain that Torås was chosen as a key site for joint MI6, CIA and Norwegian Intelligence Service (NIS) 
training operations. In the event of a Soviet occupation, Torås would also have been used as a hidden base for clandestine resistance operations as part of the NATO 'Stay Behind' programme, otherwise known as Operation Gladio (Riste 2007).

From the generator room, we climb some more steps and enter another large chamber with a curved ceiling, almost identical to the first, then take a hard right through a steel blast door into another tunnel. Suddenly we see a rectangle of daylight against the blackness, and head for the exit. We emerge about 100 meters further up the hillside onto a narrow asphalt track lined on either side with overhanging trees and giant glacial rock formations. Further into the base and a few steps up the road, we spot another blast door set back into the rockface. Easing it open we enter a network of tunnels more ruinous, more fascinating and more unsettling than the last.

\section{Black Mould}

Pieces of broken furniture and reams of official documents lay in pools of stagnant water, barely visible through the dim illumination of our smartphone beams. We push past the vague, tremulous fear of encountering something dead, decomposed, or worse - something alive. At various points along the passage, contorted shop mannequins lay face down in the dirt, some pointing to the darkness beyond, or beckoning like the headless companion of Max Ernst's Celebes (1921). One is charred, burned to a crisp, a victim perhaps of a drunken Friday night army interrogation.

Shifting the torch around the passages and chambers, it becomes clear that black mould has taken over, painting the walls with a densely mottled fungal outbreak. Neither plant nor animal, black mould is a cryptogam, one of the 'Six Kingdoms' of organisms with hidden sex 
cells that reproduce by spores. As two of the most common black moulds, both aspergillus and strachybotrys are usually found in damp, oxygen rich environments and both are oligotrophs, a subcategory of extremophilic organisms capable of thriving on nutrientdepleted surfaces. At certain points on our journey through the tunnels, the black mould completely covers the walls and ceilings with an oppressive layer of darkness and fills the damp air with a distinct fungal tang. The odour seems to penetrate and contaminate the human body in the way that it was perhaps meant to, as a pathogen to deter or weaken invasive species (Hussein and Brasel 2001). The irony here is that many such bunkers of the Cold War era would have been sealed to exclude chemical and biological agents released as weapons over enemy territory, but now it seems that this bunker is autogenerating its own hostile environment. Any pathology of subterranean military architecture must include the study of Sick Building Syndrome in which there is a growing body of evidence to support the negative effects of fungal spores and/or mycotoxins on the human body (Fung and Hughson 2010; Gravesen et al. 1997; Mahmoodi and Gershwin 2009; Strauss 2009). Black moulds produce mycotoxins, airborne pathogenic and carcinogenic chemicals whose function is little understood (Aleksic et al. 2017), but which could serve as a 'survival mechanism' to weaken potential hosts and/or deter mammalian predators (Hussein and Brasel, 2001, p.125). Prolonged exposure to such airborne pathogens can cause significant health problems including 'skin rashes, headaches, dizziness ... chronic fatigue [and] observed inflammatory effect' (Došen, 2016, p.5513). Strachybotrys is likely to be an important contributing factor in 'allergic sensitisation, inflammation, and cytotoxicity in the upper and lower respiratory tracts' in animal test subjects as they succumb to simulated 'damp building-related illness[es]' (Pestka et al. 2008, p.20). Cytotoxicity is the ability of some chemical and organic compounds to destroy living cells, and 'interfere with key processes like RNA and DNA synthesis' (Gniadek et al 2011, p.59). Without a microscopic analysis, it is almost impossible 
to tell which of the species of Aspergillus or Strachybotrys (or indeed, other black moulds) is most prevalent in the tunnels of Torås, but it seems likely that prolonged exposure to either (or both) could be detrimental to human health. The intensity of the smell is overwhelmingly invasive, the air seemingly thick with spores and mycotoxins, an atmosphere of fungal propagation and transformation. There is an overwhelming sense that this is a space no longer meant for humans, that we are the invasive species.

\section{Efflorescence}

It is impossible to tell when the ingress of water began in these tunnels and chambers, when the concrete, bricks and gypsum eventually failed against the intermolecular forces of this capillary action acting in union with the monstrous weight of the mountain above. It is curious to imagine how the passage of mountain water through fissures in granite and porous layers of brick eventually nurtured long dormant life forms within these seemingly impenetrable cavities. Perhaps even stranger is the fact that such water will also trigger the process of crystallisation on the surface of the walls. The irregular white patches we sometimes see on brickwork and concrete is efflorescence, dried deposits of salt and other soluble minerals, leaching down walls and brickwork and blooming unexpectedly on new and old building alike. However, in the bunker caves of Torås, efflorescence hangs from the walls and ceilings like fibrous bunches of cotton, or delicate beards of fungus that could easily disintegrate if touched (see Fig 2).

[insert Fig 2. Here\}

Such abundant growth provokes a physical revulsion: it is not simply the fear of contact and contamination, but the body instinctively rejects this exuberant expression of decay, as if 
entropy itself is contagious. In some rooms the growth is everywhere - above, around and underfoot, brushing against us in the darkness as we navigate the confined space with our phone torches. This crystal world does not evoke the poisonous beauty of Roger Hiorns' installation Seizure, created in a south London council flat using 75,000 litres of copper sulphate to grow a floor-to-ceiling crystalline environment, a kind of walk-in geode or agate grotto (Hiorns 2008). Nor is this the Crystal World of J.G. Ballard in which trees, forests and animals slowly turn to crystal in a Gabon forest, triggering for the protagonist 'a thousand images of childhood ... recalling the paradisal world when everything seemed illuminated by that prismatic light described so exactly by Wordsworth in his recollections of childhood.' (2014, p.69). In the tunnels of Torås, the exuberant accretion of salt crystals offers only the perverse paradox of growth in decay, and an inexorable transformation of architectural space by the mineral world, in its alien-to-us form of cultural production.

While efflorescence is principally regarded as an aesthetic problem in the building industry, the build-up of "crystalline salts within pores near the surface (crypto-efflorescence)... may result in exfoliation or spalling' of the concrete or masonry (Brocken and Nijland 2004, p.315). Water gradually dissolves the soluble constituents of the building materials, which in concrete is coarse aggregates and cement (calcium silicate, lime, gypsum etc.), and secretes them on the surface. During the dehydration process, the solution then reconfigures as sodium sulphate crystals (Rodriguez-Navarro, Doehne and Sebastian 2000), and depending on the variety of sodium sulphate (determined by the constituents of the concrete or brick), the crystals will form in different ways. However, their formation is also determined by the flow and availability of water.As less water becomes available 'smaller crystals will form with rounded edges. With decreasing water availability, fibrous crusts will form, with columnar crystals growing perpendicular to the surface and away from it. This is finally followed by the formation of whiskers, i.e., very thin crystals' (Charola and Bläeur 2015, 
p.125). This whiskery formation of efflorescence is certainly evident in the tunnel bunkers at Torås, sprouting in curiously uniform patches several inches thick and in broken lines like the dots and dashes of Morse code. The suggestion of a crypto-language recalls the florid, fungoid letters projecting from the walls of the subterranean 'tower' in Jeff VanderMeer's novel Annihilation (2015), a phenomenon which ultimately leads the protagonist to encounter the once-human 'crawler' in the depths of the structure.

\section{Mycelium and art}

One of the tunnels suddenly opens out into a large rectangular room. Judging by a set of long shelves across one half of the room, this was almost certainly a storage area of some kind, and we discover a loose collection of disintegrating canvas bags, building plans, old batteries spewing white corrosion onto surrounding surfaces, hand-written letters, administrative notes, and most improbable of all, a collection of framed paintings and prints (See Fig 3).

[Insert Fig.3 here]

It seems that this bunker has its own art collection. These works of art are all extensively covered in blooms of mildew, foxing, fungi and orange rust stains from the microscopic particles of metal in the paper. Some pictures are so disfigured with mould and fungi attack that they resemble three-dimensional relief paintings of alien landscapes saturated with moisture and bulging with protean life forms. The peculiarity of these self-generating, living artworks stop us in our tracks, and we pause to consider how they could thrive on such a surface in such a place. Constrained as they are within a wooden rectangular frame, and without obvious resources they, nevertheless, seem able to grow in unfettered abundance consuming and dominating the surrounding environment. Indeed, the high relative humidity and often sub-zero temperatures are the perfect habitat for 'enormously diverse and 
metabolically active fungal communities' (Wang et al. 2017, p.179). The extremophilic robustness of such fungi is evidenced in recent studies of airborne micro-organisms collected at several 'historic era' exploration huts on Ross Island, Antarctica. These huts werefamously built and used by Scott, Shackleton and others at the beginning of the Twentieth Century (Duncan et al. 2010, p.281). The most abundantly found fungal genera were Cadophora, Cladosporium, Geomyces, Cryptococcus, Hormonema, Rhoturula, Fusarium, and a number of types of Penicillium. At Torås, we struggle to identify the individual genera thriving on the paintings and prints, but several fungi of varying colours and shapes - some fleshy and substantial, others like wisps of the finest hair dotted with pinhead-like sporangia - seem to merge into a parasitic or mutualist mass. Despite lacking the singular agency of a trained painter, this fungal abstraction resembles certain works by Ivan Albright (1897-1983) who was commissioned to paint the grotesque portrait seen in the feature film, The Picture of Dorian Grey (1945), that narrative of moral corruption and deferred entropy by Oscar Wilde. However, one beautiful oil painting of an island landscape is the subject of a different kind of transformation. A snowy mountain range plunges into the cold, azure sea, which laps against a rocky shore in the foreground. The larger rocks resemble the whale-like granite formations across the Oslo Fjord, but the mountains could easily be the islands of Lofoten off the east coast or even Svalbard in the High North. Closer inspection reveals something out of place as a fungal organism sprouts from the rocks (see Fig.4 and 5).

[Insert Fig.4 here]

[Insert Fig. 5 here]

Like an inverted lightning strike, its jagged bolts discharge to form a complex filigree of mycelium threads, endlessly subdividing and branching out across the surface of the imageperhaps searching for sustenance amongst the aged pigments, solidified linseed oil and 
canvas fibres. Mycelium is the hyphae, the root-like cellular network of a saprophyte, which channels nutrients across great distances to form 'fruit' in the form of mushrooms that break down rotting organic matter. In his speculative and influential book Mycelium Running, mycologist Paul Stamets describes fungi as 'interface organisms between life and death' (2004, p.1), and argues that because of its sheer scale, complexity and resemblance to an 'externalised neurological net', mycelium could relay data regarding the life and death of organisms across vast landscapes - a 'fungal internet' of sorts (2004, p.4). Indeed, these observations were prompted by Stamens' realisation that the mycelium network resembles nothing less than the logic maps of the Advanced Research Projects Agency Network (ARPANET), an early version of the internet funded by the United Stated Department of Defence, which connected supercomputers at universities around the USA (2008). ARPANET was tangentially derived from RAND Corporation's research into robust information communications systems that could withstand a nuclear war. Similarly resilient, mycelium is fundamental to connecting, preserving, and strengthening natural ecosystems, rapidly identifying and breaking down matter as part of an essential and highly efficient life cycle. More recent work on mycelium seems to confirm Stamets' hypothesis that fungal hyphae (as mycorrhizal networks) form an interface between plants, connecting them across great distances and triggering 'behavioural responses' among diverse communities of plant species (Gorzelak et al. 2015, p.2).

The mycelium before us, pressed between glass and image, searches for nutrients across a painted Nordic landscape. Reading the mountains and shorelines, its cotton-fine hyphae blindly samples the rocks and ravines, laying digestive enzymes across the rippling blue sea. It has become a hungry consumer of art but has also seamlessly drawn itself into the narrative of the image: an alien spore adrift in the universe comes to rest on a rocky Norwegian shore, and then begins its search for sustenance and stealthy domination. As heterotrophs, fungi and 
their mycelial networks survive by absorbing molecules dissolved in water, and because they do not photosynthesise, they do not require light to survive. Some are also adept at absorbing and processing various forms of ionizing radiation which leads to increased growth, as observed in 'fungal species [which] colonize the walls of the highly radioactive damaged reactor at Chernobyl ... and surrounding soils' (Dadachova and Casadevall 2008, p.1). In all ways, fungal communities are much more suited to long term survival in bunkers than humans.

Torås is just one of thousands of Cold War sites across the world. Some, no doubt, remain pristine and unopened, while many others have succumbed to the natural forces of entropy. A review of blogs, websites and message platforms by urban explorers and bunker enthusiasts reveal innumerable Cold War subterranean sites across the UK, Europe, Russia and the USA, with similar levels of ruination and invasion by fungal genera, efflorescent or rust degradation. The explorer forums 28dayslater.co.uk and oblivionstate.com have countless pages describing Royal Observer Corp and civil defence bunkers, some knee deep with water and the floating corpses of stray sheep or lost cats, others have become remote enclaves for teenage transgression or burnt-out drug dens. Similarly, with the comprehensive explorer community website subbrit.org.uk, it is possible to view pages of dilapidation and ruin, and identify similar characteristics of entropy across many different sites (each superimposed with human representational and taxonomic frames of interpretation as analysed by Bennett, 2013). One common theme is that each of these spaces has been compromised by an ingress of water or subject to high levels of relative humidity. Water activates the fungal spores present in almost every human environment, and quickly undermines the integrity of mineralbased construction materials. The questionable logic of building or retrofitting Cold War bunkers in caves is highlighted by Maria Alejandra Pérez who, on an exploration of the civil defence bunker-caves in Greenbier County, West Virginia, observes that: 
... signs of leaks could spell serious sign of its vulnerability, its eventual ruination. In a cave, they are a sign that it is alive. Drips within caves remind us that these spaces continue to morph, to grow. In some cases, the rates of change are so fast that in just a matter of just a few years highly soluble calcites from the limestone reconfigures itself as stalactite, stalagmites and a myriad [of] other intriguing forms. ... [S]igns of a breach in an otherwise unbreachable container $(2017, \mathrm{p} .121)$

These observers then examine and aestheticize the inexorable change at play within these spaces - and their unsuitability to human habitation. This hostile environment is curiously the product of both entropy and the fecundity of non-human generative forms.

The paradoxical binaries of decay and life, destruction and survival, continuity and changes, were also salient themes in the counter-cultures and scientific endeavours of the Cold War era. The following section will draw on the connections between these cultural and scientific undercurrents to support the idea that the concept of entropy is fundamental to a comprehensive understanding of the Cold War bunker.

\section{Entropy, Homeostasis and Cybernetics}

Sarah Boyle is the protagonist in Pamela Zoline's experimental short story, Heat Death of the Universe. 'A vivacious and intelligent young wife and mother, educated at a fine Eastern college, proud of her growing family which keeps her busy and happy around the house' (Zoline 1988, p.15), Boyle also functions as an observer of entropy, yearning to keep the action of the Cold War at bay through her obsessive counter-project of decontamination. 
Zoline uses Boyle's quiet obsession with the concept of entropy to measure theincreasing disorder in the universe- a fact that will, one day, lead to the complete dispersal and destruction of particles within it. While arranging children's parties and bulk buying massproduced goods, Boyle speculates on the end of the world by ice, water, nuclear war, and by the hyper-localised decay she observes in her appearance and that of her friends. Published in 1967 and conceived at the height of both the Cold War and the Vietnam War, Heat Death reads like a list of laboratory notes with Boyle, her family and a constellation of every-day commodities as the subjects. It also positions classical physics as the underlying source of Boyle's existential dread, draining the energy from everyday tasks and revealing the eventual chaotic dissipation of all energy. As a microcosm of middle-class American life, her everyday existence is seen here as a localised expression of the Second Law of Thermodynamics, where domestic continuity is threatened by tiny observations of decay, the quantifiable units of entropy. Zoline's short story provides a layman's introduction to the concepts of entropy and homeostasis, but places them within the context of possible nuclear war and the eventual unwinding of the universe towards its inevitable 'heat death' where no more energy is available for use. To mitigate the effects of entropy, she imagines 'cleaning, and ordering the great world, even the Universe. Filling the great spaces of Space with a marvellous sweet smelling, deep cleansing foam. Deodorizing rank caves and volcanoes. Scrubbing rocks' (p.26). She also finds a chink of hope for humanity in the work of physicist Norbert Wiener who, contrary to the orthodoxy of classical physics, believed that:

... man, tend[s] for a time to maintain and often even to increase the level of their organisation, as a local enclave in the general stream of increasing entropy, of increasing chaos and de-differentiation. Life is an island here and now in a dying world. The process by which we living beings resist the general stream of corruption and decay is known as homeostasis. (Wiener 1989, p.95) 
Homeostasis is the term used to describe the ability of living organisms to regulate their internal environments using feedback loops which adjust metabolic processes in response to sense stimulations from the outside world. For Thomas Pynchon, another scholar of Cold War science, who 'happened to read Norbert Weiner's The Human Use of Human Beings' (Pynchon 1995), entropy was a salient themes in his early fictions. Indeed, in his short story Entropy from 1960, we enter a 'lease-breaking party' in a hermetically sealed apartment, 'a tiny enclave of regularity in the city's chaos' (p.83). This homeostatic 'hothouse jungle' is a carefully controlled ecological feedback loop of plants, animal and humans, but the system is eventually undermined when a character deliberately punches a hole in a window.

For Norbert Wiener, the study of homeostatic feedback mechanisms was the basis for his highly influential theory of cybernetics (Wiener 1961). Here, the observed capacity for living organisms to self-organise and self-regulate in apparent defiance of the entropic imperative, became the basis for analogous mathematical formulae and computational models. Wiener recognised that the homeostatic feedback loop was effectively a system for gathering and articulating information, within which there are nested hierarchies of systemic priorities. Understanding these adaptive 'communication' systems would be key to developing artificial or synthetic systems with a range of real-world applications in fields such as molecular biology, artificial intelligence, complex communication systems, and even forms of state, cultural and economic governance (Rindzeviciute 2008, Medina 2006).

The military-industrial establishments of the USA and the Soviet Union seized on the potential of cybernetics and advances in computing to revolutionise the way modern warfare was conducted. The proliferation of atomic weapons during the nuclear arms race, and the potential speed of their delivery, suggested that only a machine with considerable processing 
power could be expected to form a successful counter strategy within increasingly narrow time frames. The development of SAGE (Semi-Automated Ground Environment) harnessed the concept of a 'closed cybernetic loop between computer and user' to rapidly relay strategic information between sensors (radars) and outputs (missile and weapons system behaviour), as part of a cutting-edge centralised air defence network (Bousquet 2009, p.132). However, SAGE was only one element of a rapidly evolving systematisation of military strategic planning and technological development. As Bousquet suggests:

Cybernetics, along with operations research and systems analysis, sought to impose order and predictability on warfare through the collection, processing, and distribution of information ... which saw military organization purely as a vast techno-social machine to be integrated and directed on the basis of the predictions of mathematical models and the deployment of cybernetic technologies (p.1).

Despite its ability to bring a grandiose order to the Cold War, the failure of the cybernetic rationale was nowhere more evident than in the Vietnam War, where it disastrously created 'restrictive assumptions about conflict' (p.1), and 'an obsession with statistical evaluations' (2009, p.155), all of which lead to a wildly distorted picture of the war on the ground. While the cybernetic rationalisation of conflict could not determine complex outcomes within unpredictable and chaotic insurgencies, for instance, its legacy is embedded in the planning of modern conflicts and their reliance on command and control communication technologies.

The proliferation of bunkers and hardened shelters during the Cold War was perhaps a surprising by-product of an era in which the principles of cybernetic theory found their practical and universal application. The capacity for self-regulation, self-preservation and 
homeostasis in the face of accelerated entropy is nowhere more evident that in the Cold War bunker, for these resilient qualities are found in the replication and proliferation of nonhuman cultural production there. Humanity had simultaneously created the means of its own extinction and its preservation, and this paradox is clearly expressed in the phenomenon of the Cold War bunker. Such spaces were created in preparation for the ultimate energy-drain, the sudden dissipation of energy and the destruction of matter and organic life, but as localised subterranean enclaves created to preserve human life, they also offer refuge for other organisms.

\section{Enclaves of constancy}

The Cold War engendered an end-of-days existential cultural anxiety, into which a preoccupation with entropy found a natural home, coupled as it was with a rising ecological sensibility. This is evident in the work of artist Robert Smithson, and its concern with depletion, extractive exhaustion and environmental despoliation. Smithson's great earth work, Spiral Jetty continues to be a monument to geological redeployment and dispersal. His artworks and writing are infused with entropic processes, and his work can be read as a process of 'caustic defamiliarization' (Beck 2009, p.245), in which architectural and industrial processes are unexpectedly set against the geological landscapes of deep time and microscopic granularity. As the 'one dominant theme that ran through everything' (Smithson 1996, p.293), entropy informed an interest in 'kind of low-profile landscapes, the quarry or the mining area which we call entropic landscapes, a kind of backwater or fringe area' (p.298). To these low profile or entropic landscapes, we might add the numerous civil defence shelters, missile launch silos and government bunkers dispersed across Smithson's suburban heartland of New Jersey. Smithson's quasi-psychogeographical text, A Tour of the Monuments of Passaic, New Jersey from 1967 (Flam 1996), includes speculative and 
philosophical engagements with prosaic forms of infrastructure, sewages outlets and children's sandpits, all seen through the dual lenses of the infinite and the microscopic. Had they been at all visible, Smithson would perhaps have been drawn to the fourteen Nike Ajax surface-to-air missile installations distributed across the wastelands and suburbs of New Jersey to defend the Eastern Seaboard against Soviet bombers. Had he lived beyond 1973, Smithson would possibly have also drawn upon the entropic paradoxes of the subterranean bunker and its concealed monumentality, as it emerged in later years from the secrecy of the Cold War into public consciousness.

Published two years after Smithson's death, Paul Virilio's theoretical text on the bunkers and beach defences of the Atlantic Wall, Bunker Archeology (1975) remains a lodestar for many scholars of defence architecture and military space. It shares with Smithson's work similar themes of accidental monumentality (Smithson 1996, p.68; Virilio, p.121), and the placing of architectural elements and infrastructural space within the deep timeframe. Indeed, Virilio's suggestion that 'the military institution is a cyclothymic animal hibernating in peacetime and awake for war' (p.21), is nowhere more apparent than in the phenomenon of the Cold War bunker which remains dormant until such a time as it is needed. And yet, 'cyclothymic' is a very specific and loaded term, referring perhaps to the psychological condition of cyclothymia, a bipolar mood disorder in which the sufferer swings between periods of depression and hypomania (Parker and Fletcher 2012). It may or may not have been Virilio's intention to couch the shifting timeframes of peace and militarisation in the language of psychopathology, but it is, however, useful for our purposes to consider the Cold War bunker as a form of architecture designed and constructed under the mushroom cloud of Mutually Assured Destruction (MAD) - which future clinicians will surely diagnose in pathological terms. Cold War bunkers are a material expression of an unprecedented political and societal 
moment, a state of global anxiety in which the auto-destruction of humanity is a very real possibility. And yet is also worth considering that such architecture represents a rational and rather prosaic urge to preserve the species, albeit in a very reduced form.

As enclaves of continuity and constancy, Cold War bunkers were built to preserve human life for a finite period in the event of a nuclear exchange, but in the absence of such a catastrophe these sites will exist in near-perpetuity, providing shelter and a predator-free environment for fungi and other extremophilic organisms into the distant future. Indeed, they will persist beyond any limited incineration of the Earth's surface, beyond the projected increase in global temperatures caused by man-made carbon emissions, nurturing numerous species of saprophytes until such a time that they can lay claim to the surface.

\section{Conclusions}

The bunker identifies and isolates a paradox - the reality of growth in decay. As an incubator for such processes, the Cold War bunker can be regarded as laboratory for entropic transformations, and the perfect point of departure for broader cultural analyses of material dissolution in the age of atomic weapons. Entropy has been considered here as both a measure of the dissolution of energy within the Second Law of Thermodynamics, and as a metaphor for a kind of cultural anxiety associated with the Cold War and its threat of nuclear annihilation, ruination and decay. Indeed, the article has argued that it is no coincidence that the cultural resurgence of interest in entropy occurred during the Cold War, the era in which the human race first acquired the capacity to annihilate itself. It is perhaps not surprising that entropy was also the point of departure for the development of cybernetics, which we might consider as the underlying 'logic' of the Cold War: cybernetics facilitated the technological convergence of computational power, communication systems, remote sensors and weapon 
systems, all feeding back information within an integrated closed system. If such a system had an inclination to preserve itself, it was surely expressed in the thousands of underground bunkers built during this period.

If the apparent father of cybernetics, Norbert Wiener, characterised life as 'local and temporary islands of decreasing entropy in a world' (Wiener, 1989, p.44), he did so in the belief that life somehow represents 'progress' in a universe that was ultimately unwinding in the opposite direction. Wiener was not only referring to humanity, but all life on a molecular level. In this respect, it is perhaps ironic that while Cold War bunkers were produced to preserve the vestiges of humanity, they might ultimately incubate and nurture other species of life.

\section{References}

28 Days Later, urban explorer forum, retrieved December 10, 2018, available from: https://www.28dayslater.co.uk

Alejandra Perez, M., 2017. Bunker and Cave Counterpoint: Exploring Underground Cold War Landscapes in Greenbrier County, West Virginia. In: L. Bennett, ed. In the Ruins of the Cold War Bunker: Affect, Materiality and Meaning Making, London: Rowman \& Littlefield, 113-129.

Aleksic, B., et al., 2017. Aerosolization of mycotoxins after growth of toxinogenic fungi on wallpaper. Applied and Environmental Microbiology. 83(16).

Ballard, J., 2014. The Crystal World. London: Fourth Estate.

Beck, J., 2009. Dirty Wars: Landscape, Power, and Waste in Western American Literature. Lincoln: University of Nebraska Press.

Bennett, L., 2013. 'Concrete Multivalence - practising representation in bunkerology', Environment and Planning D: Society and Space31:502-521. 
Bennett, L., ed., 2017. In the Ruins of the Cold War Bunker: Affect, Materiality and Meaning Making. London: Rowman \& Littlefield.

Bosma, K., 2012. Shelter City: Protecting Citizens Against Air Raids. Amsterdam: Amsterdam University Press.

Bousquet, A., 2008. Chaoplexic warfare or the future of military organization. International Affairs. 84(5), 915-929.

Bousquet, A., 2009. 'The scientific way of warfare', Order and chaos on the battlefields of modernity, London: Hurst.

Bousquet, A., 2008. 'Cyberneticizing the American war machine: Science and computers in the Cold War', Cold War History, 8(1) 77-102.

Brocken, H., \& Nijland, T. G., 2004. White efflorescence on brick masonry and concrete masonry blocks, with special emphasis on sulfate efflorescence on concrete blocks. Construction and Building Materials, 18, 315-323.

Burke, R., 2003. The Fed's Very Own Cold War Bunker. Virginia Business. February.

Ernst, M., 1921. Celebes. Painting.

Charola, A. E., Bläuer, C., Pinetti, A., Zanini, P., Shahidzadeh-Bonn, N., Navarro, C. R., \& Svane, M., 2015. Salts in Masonry: An Overview of the Problem. Restoration of Buildings and Monuments, 21, 119-135.

Cockcroft, W. D., Thomas, R. J. C., \& Barnwell, P. S., 2004. Cold War: Building for Nuclear Confrontation 1946-1989. Swindon: English Heritage.

Dadachova, E., \& Casadevall, A., 2008. Ionizing radiation: how fungi cope, adapt, and exploit with the help of melanin. Current Opinion in Microbiology, 11(6), 525-531.

Czechowski W., Rutkowski T., Stephan W., Vepsäläinen K., 2016. Living beyond the limits of survival: wood ants trapped in a gigantic pitfall. Journal of Hymenoptera Research, 51, 227-239.

Davis, T. C., 2007. Stages of Emergency: Cold War Nuclear Civil Defense. Durham NC: Duke University Press.

Došen, I., Andersen, B., Phippen, C. B. W., Clausen, G., \& Nielsen, K. F., 2016. Stachybotrys mycotoxins: from culture extracts to dust samples. Analytical and Bioanalytical Chemistry, 408(20), 5513-5526.

Duncan, S. M., Farrell, R. L., Jordan, N., Jurgens, J. A., \& Blanchette, R. A., 2010. Monitoring and identification of airborne fungi at historic locations on Ross Island, Antarctica. Polar Science, 4(2), 275-283.

Flam, I., ed., 1996. Robert Smithson: The Collected Writings. Berkeley: University of California Press. 
Flintham, M., 2016. Torås Kommandoplass: Observations from a dark summit. Critical Military Studies, 2(3), 271-277.

Flintham, M., 2017. Torås Fort: A Speculative Study of War Architecture in the Landscape, in Bennett, L, ed. In the Ruins of the Cold War Bunker: Affect, Materiality and Meaning Making, London: Rowman \& Littlefield, 97-111.

Fung, F., Hughson, W.G., 2003. Health Effects of Indoor Fungal Bioaerosol Exposure, Applied Occupational and Environmental Hygiene, 18(7), 535-544.

Gniadek, A., Macura, A. B., Górkiewicz, M., 2011. Cytotoxicity of Aspergillus Fungi Isolated from Hospital Environment. Polish Journal of Microbiology, 60(1), 59-63.

Graff, G. M., 2017. Raven Rock: The Story of the U.S. Government's Secret Plan to Save Itself - While the Rest of Us Die. New York: Simon \& Schuster.

Gravesen, S., Nielsen, P.A., Nielsen, K.F., 1997. Microfungi in Water Damaged Buildings. SBI Report 282. Danish Building Research Institute, Copenhagen.

Gorzelak, M. A., Asay, A. K., Pickles, B. J., Simard, S. W., 2015. Inter-plant communication through mycorrhizal networks mediates complex adaptive behaviour in plant communities. AoB PLANTS, 7(1).

Herzog, R., 2014. A Short History of Nuclear Folly: Mad Scientists, Dithering Nazis, Lost Nukes, and Catastrophic Cover-Ups. New York: Melville House.

Hiorn, R., 2008. Seizure. site-specific installation. Elephant \& Castle housing estate, London.

Hirst, P., 2005. Space and Power: Politics, war and architecture. Cambridge: Polity.

Hussein, H. S., Brasel, J. M., 2001. Toxicity, metabolism, and impact of mycotoxins on humans and animals. Toxicology, 167(2), 101-134

Jumeau, J., Wolf, D., Guthmann, L., Gorlero, N., Burel, F., Handrich, Y., 2018. The use of military bunkers by the European badger and red fox in Western Europe. Urban Ecosystems, 21(2), 395-403.

The Picture of Dorian Gray, 1945. Film. Directed by Albert Lewin, USA: Metro-GoldwynMayer.

Leonard, B., 2015. History of Strategic Air and Ballistic Missile Defense: Volume II 19561972. CreateSpace.

Mahmoudi, M., Gershwin, E., 2000. Sick Building Syndrome. III. Stachybotrys chartarum, Journal of Asthma, 37(2). 191-198.

McCamley, N., 2013. Cold War Secret Nuclear Bunkers. Barnsley: Pen \& Sword Military.

McEnany, L., 2000. Civil Defense Begins at Home: Militarization Meets Everyday Life in the Fifties. Princeton: Princeton University Press. 
Medina, E., 2006. Designing freedom, regulating a nation: Socialist cybernetics in Allende's Chile. Journal of Latin American Studies, 38(3), 571-606.

NORAD. Cheyene Mountain Complex. Official website available from:

http://www.norad.mil/About-NORAD/Cheyenne-Mountain-Air-Force-Station/ [accessed 19 December 2019]

Parker, G., McCraw, S., Fletcher, K., 2012. Cyclothymia. Depression and Anxiety. 29(6), 487-494

Pestka, J. J., Yike, I., Dearborn, D. G., Ward, M. D. W., Harkema, J. R., 2008. Stachybotrys chartarum, Trichothecene Mycotoxins, and Damp Building-Related Illness: New Insights into a Public Health Enigma. Toxicological Sciences, 104(1), 4-26.

Pynchon, T., 1995. Slow Learner. London: Vintage.

Rindzeviciute, E., 2008. Constructing Soviet cultural policy: Cybernetics and Governance in Lithuania after World War II. Thesis (PhD). Linköping University Press.

Riste, O., 2007. With an eye to history: The origins and development of 'Stay-Behind' in Norway, Journal of Strategic Studies, 30(6), 997-1024

Rodriguez-Navarro, C., Doehne, E., Sebastian, E., 2000. How does sodium sulfate crystallize? Implications for the decay and testing of building materials. Cement and Concrete Research, 30. 1527-1534.

Schlosser, E., 2014. Command and Control. London: Penguin.

Smithson, R., 1970. Spiral Jetty. Site specific earthwork, Great Salt Lake nr Rozal Point, Utah.

Sørlie, R., 2009. Festung Tjøme: Tysk okkupasjon av Tjøme 1940-45, self-published.

Stamets, P., 2004. Mycelium Running. Berkeley: Ten Speed Press.

Stamets, P., 2008. 6 Ways Mushrooms Can Save the World [video file]. Retrieved from: https://www.ted.com/talks/paul_stamets_on_6_ways_mushrooms_can_save_the_world [accessed 19 December 2018]

Straus, D. C., 2009. Molds, mycotoxins, and sick building syndrome. Toxicology and Industrial Health. 25(9-10)

Sudakov, D., 2016. Moscow prepared for possible nuclear attack - EMERCOM. Pravda. 30 September. Available from: http://www.pravdareport.com/russia/politics/30-09-2016/135749-moscow_nuclear_war-0/ [accessed 19 December 2018]

VanderMeer, J., 2015. Annihilation, London: Fourth Estate.

Virilio, P., 1994. Bunker Archeology, New York: Princeton Architectural Press. 
Wang, M., Tian, J., Xiang, M., Liu, X., 2017. Living strategy of cold-adapted fungi with the reference to several representative species. Mycology, 8(3), 178-188.

Wiener, N., 1961. Cybernetics: Or Control and Communication in the Animal and the Machine. Cambridge, MS: MIT Press.

Wiener, N., 1989. The Human Use of Human Beings. London: Free Association Books.

Ziauddin, S. B., 2017. Superpower Underground Switzerland's Rise to Global Bunker Expertise in the Atomic Age. Technology and Culture, 58(4), 921-954.

Zoline, P., 1988. The Heat Death of the Universe and Other Stories. New York: McPherson. 